\title{
Svangerskapsrelaterte bekkenplager
}

Det fødes 60000 barn i Norge hvert år, og mange av disse barnas mødre har slitt med smerter i bekken og korsrygg under svangerskapet. Plager i svangerskapet er årsak til omtrent en tredel av all sykmelding hos kvinner i alderen 20-35 år, av disse igjen er smerter i bekken og korsrygg vanligste årsak til sykmeldingen. Svangerskapsrelaterte bekkenplager har fått mye oppmerksomhet i mediene. Det er lett å bli skremt av de mange oppslag om invalidiserende smerter under og etter svangerskap, og mange ulike utøvere fallbyr behandling med tvilsom eller fraværende dokumentasjon. I dette nummer av Tidsskriftet drøfter Britt Stuge diagnostikk og behandling av bekkenleddsplager (1).

Begrepet «bekkenløsning» er svært godt innarbeidet i befolkningen og vil nok være vanskelig å endre. Årsaken til at man får bekkensmerter er imidlertid fortsatt ukjent, og det er ikke vist noen sammenheng mellom løshet i bekkenleddene og smerter. Skal man bruke termen bekkenløsning, bør man skille mellom den fysiologiske tilstanden, som betegner noe økt føyelighet i ligamentene uten spesielt stort funksjonstap, og symptomgivende bekkenløsning. Det beste er nok å bruke «svangerskapsrelaterte bekkenplager», fordi denne betegnelsen ikke impliserer noen etiologisk slutning. Insidensen av bekkensmerter i svangerskapet rapporteres til mellom $20 \%$ og $45 \%$. I en studie fant man at $99 \%$ av kvinnene var uten plager tre måneder etter fødselen og at type behandling i svangerskapet hadde liten betydning for problemene etter fødselen (2). Dette kan tyde på at svangerskapsrelaterte bekkenplager i hovedsak er en normaltilstand og at forløpet stor sett er godartet.

Sterke smerter, økt psykisk stress og positiv P4-test (posterior pelvic pain provocation test, smerteprovokasjon av bakre bekken) tidlig i svangerskapet predikerer mer smerte og dårligere funksjon i 30. uke (3). Sterke smerter i svangerskapet gir mer plager og funksjonssvikt etter fødselen (4). Ryggsmerter før svangerskapet $\mathrm{i}$ kombinasjon med bekkensmerter under graviditeten er også en negativ prediktor. Det er følgelig god grunn til å fange opp dem som sliter i svangerskapet. Smertetegning og P4-test er nyttig i denne sammenheng og lett og raskt å utføre. Sjeldne, men viktige differensialdiagnoser etter fødselen er iliosakralleddsartritt og lumbal nerverotsaffeksjon. Debut av Bekhterevs sykdom, psoriasisartritt og revmatoid artritt er sjeldent, men kan forekomme etter en fødsel.

Mistanken må skjerpes ved uttalt morgenstivhet og sterke smerter over ileosakralleddene. Laboratoriestatus og MR av ileosakraledd vil avklare dette. Graviditet er en risikofaktor for skiveprolaps, som kan bekreftes ved lumbal MR. Ellers er det sjelden at supplerende undersøkelser gir positive funn. Den vanligste differensialdiagnosen er lumbale ryggsmerter. Et blandet bilde forekommer ofte og er en negativ prediktor. Er P4-testen positiv bilateralt og kvinnen rapporterer økende smerter ved og særlig etter belastning (kveldssmerter), styrkes mistanken om bekkensmerter. I Norge brukes begrepet «kronisk bekkenleddssyndrom» om smerter i bekkenet som vedvarer utover tre måneder, selv om sammenhengen med bekkenleddene er uklar. Den engelske betegnelsen «pelvic girdle pain» foretrekkes i de europeiske retningslinjene (5), men kan ikke lett oversettes. Begrepsbruken reflekterer den uavklarte etiologien.

Kvinner med bekkensmerter etter fødselen har gjerne forskjellige og sammensatte problemer. Det gjelder derfor å gå systematisk gjennom de ulike områdene hvor problemer kan oppstå for å bestemme hvor behandling kan settes inn. Tiden etter fødselen skal være en lykkelig periode hvor familien står i sentrum. Dersom kvinnen etter fødselen har mye smerter, ikke kan stelle barn og hus og ikke kan fylle de forventningene hun og de rundt henne har, kan dette bli en belastning for alle i nettverket. Enkelte kvinner utvikler behandlingstrengende depresjon. Legen kan hjelpe ved å realitetsorientere paret rundt situasjonen, veilede dem om fordeling av arbeidsoppgaver, planlegging og organisering av livet samt fremheve at det er gode muligheter for bedring og progresjon i aktivitet. Dette gjelder også i forhold til arbeidsplassen dersom kvinnen ikke er fullt arbeidsfør etter permisjonen. Arbeidsgiver bør kontaktes tidlig for tilrettelegging, da kan sannsynligvis behovet for sykmelding reduseres ved enkle tiltak. Råd om søvnhygiene og bruk av lette innsovningsmidler kan bedre søvnmengde og -kvalitet, noe som er viktig for smerteopplevelsen. Fysioterapi gis full refusjon ved bekkenplager i seks måneder etter fødselen. Enkle myalgier kan respondere godt på muskulær behandling. En norsk studie viste at individuelt tilpassede stabiliserende øvelser i 20 uker ga mindre smerte og bedret funksjon på kort og på lang sikt (to år) (6). I en annen studie fant man imidlertid ingen forskjell mellom stabiliserende øvelser via videoinstruksjon og rådgivning i åtte uker (7). Det kan se ut som individuell tilpasning ved fysioterapeut er viktig. Fysisk aktivitet kan også gi bedre mestringsevne. Ved manglende resultater etter $8-12$ uker bør behandlingsfokus vurderes. Mye terapeutkontakt kan sykeliggjøre kvinnen.

Dette er en kvinnesykdom med smerte som hovedsymptom og som regel uten objektive funn, noe som dessverre sannsynligvis fører den langt ned på det medisinske hierarki av sykdommer. I dag har ingen medisinsk spesialitet et definert ansvar for denne gruppen. Et minstemål bør være at noen påtar seg den oppgaven. Til tross for at mange medieoppslag signaliserer det motsatte, er altså svangerskapsrelaterte bekkenplager en selvbegrensende tilstand - med lykkelig utgang. Ytterst få kvinner med kronisk bekkenleddsyndrom får behov for varige trygdeytelser og tilpasning av hjelpemidler.

Niels Gunnar Juel

ngju@uus.no

Niels Gunnar Juel (f. 1957) er seksjonsoverlege ved Avdeling for fysikalsk medisin og rehabilitering, Oslo universitetssykehus, Ullevål.

\footnotetext{
Litteratur

1. Stuge B. Dignostikk og behandling av bekkenleddsplager. Tidsskr Nor Legeforen 2010; 130: 2141-5

2. Elden $\mathrm{H}$, Hagberg $\mathrm{H}$, Olsen MF et al. Regression of pelvic girdle pain after delivery: follow-up of a randomised single blind controlled trial with different treatment modalities. Acta Obstet Gynecol Scand 2008; 87: $201-8$.

3. Robinson HS, Veierod MB, Mengshoel AM et al. Pelvic girdle pain - associations between risk factors in early pregnancy and disability or pain intensity in late pregnancy: a prospective cohort study. BMC Musculoskelet Disord 2010; 11:91.

4. Gutke A, Lundberg M, Ostgaard HC et al. Impact of postpartum lumbopelvic pain on disability, pain intensity, health-related quality of life, activity level, kinesiophobia, and depressive symptoms. Eur Spine J 2010; 19. E-publisert 1.7.2010.

5. Vleeming A, Albert HB, Ostgaard $\mathrm{HC}$ et al. European guidelines for the diagnosis and treatment of pelvic girdle pain. Eur Spine J 2008; 17: 794-819.

6. Stuge B, Holm I, Vollestad N. To treat or not to treat postpartum pelvic girdle pain with stabilizing exercises? Man Ther 2006; 11: 337-43.

7. Mens JM, Snijders CJ, Stam HJ. Diagonal trunk muscle exercises in peripartum pelvic pain: a randomized clinical trial. Phys Ther 2000; 80: 1164-73.
} 